Original Article

\title{
IN VITRO EVALUATION OF IMMUNOMODULATORY ACTIVITY OF ETHANOLIC EXTRACT OF MORINGA CONCANENSIS NIMMO
}

\author{
SHANTILAL SINGUNE* , J. S. VAGHELA \\ Bhupal Nobles University, Maharana Pratap Station Road, Sevashram Circle Udaipur 313001 Rajasthan India \\ Email: cipshan123@gmail.com
}

Received: 18 Mar 2020, Revised and Accepted: 22 May 2020

\begin{abstract}
Objective: The present study was undertaken to evaluate immunomodulatory activity of ethanolic extract and isolated compound from the whole plant of Moringa concanensis Nimmo

Methods: Immunomodulatory activities were determined by in vitro models-plaque-forming cell assay, nitric oxide (NO) radical scavenging activity, inhibit RAW 264.7 macrophage cell line from generating harmful NO induced by lipopolysaccharide (LPS) and MTT [3-(4,5-dimethylthiazol-2-yl)2,5-diphenyltetrazolium bromide] assay.

Results: Showed significant $(\mathrm{P}<0.01)$ phagocytic effect on human neutrophils in the parameters studied. Scavenged nitric oxide radical by ethanolic extract of Moringa concanensis inhibition 34\% and isolated compound scavenged nitric oxide radical inhibition 44\% respectively compared to control group exerted $52 \%$ decrease of nitric oxide radical respectively concentration at $0.1,0.01$ and $1.0 \mathrm{mg} / \mathrm{ml}$. LPS in murine macrophage, RAW 264.7 cells culture medium induced a high release of NO but pretreatment with Moringa concanensis extract and isolated compound resulted in inhibition of NO production by $29,37,95 \%$ and $32,44,96 \%$ at concentrations of $0.5,0.1$ and $1.0 \mathrm{mg} / \mathrm{ml}$, compared to LPS-induced sample. ethanolic extract and isolated compound significantly stimulate RAW 264.7 cell viability $(\mathrm{P}<0.001)$ by MTT assay.
\end{abstract}

Conclusion: The present experimental finding demonstrated that isolated compound has superior immunomodulatory activity than the ethanolic extract of Moringa concanensis this effect presumably due to the greater ability of an isolated compound to boost the innate and adaptive immune system.

Keywords: Moringa concanensis, Ethanolic extract, Immunomodulatory, Plaque forming cell

(C) 2020 The Authors. Published by Innovare Academic Sciences Pvt Ltd. This is an open access article under the CC BY license (http://creativecommons.org/licenses/by/4.0/) DOI: http://dx.doi.org/10.22159/ijcpr.2020v12i4.39100. Journal homepage: https://innovareacademics.in/journals/index.php/ijcpr

\section{INTRODUCTION}

A wide vary of medicative plants square measure used as AN extract for raw medication and that they possess varied medicative properties. a number of these medication square measures collected in smaller quantities by the native communities and folks healers for native use; several different raw medication square measure collected in giant quantities and listed within the market because the material by several herbal industries [1]. The system is concerned within the etiology moreover as pathophysiologic mechanisms of the many diseases. It are often modulated and this involves induction, expression, amplification, or inhibition of any half or part of the reaction [2]. Immunomodulation may be a procedure which will alter the system of an organism by interfere with its functions; if it leads to an improvement of reaction, it's named as an immunostimulatory drug that primarily implies stimulation of non-specific system. Medicinal drug implies primarily to cut back resistance against infections, stress and will occur on account of environmental or chemotherapeutical factors. Immunostimulation and immunological disorder each got to be thought of to control the traditional immunologic functioning. Therefore each immunostimulating agents and immunosuppressing agents have their standing; therefore hunt for higher agents exerting these activities is changing into the sphere of major interest everywhere the planet. many Indian medicative plants and varied 'Rasayana' are claimed to possess Immunomodulatory activity [3]. The employment of plant product as immunomodulators remains in a very developing stage. These square measure many herbs utilized in the autochthonal system. a range of plant-derived materials like polysaccharides, lectins, peptides flavonoids, and tannins are rumored to modulate the system [4]. Since precedent days, many diseases are treated by the administration of plant extracts supported ancient drugs [5]. Natural adjuvants, artificial agents, protein reagents square measure used as immunological disorder and immunostimulatory agents. However there's a significant limitation to the final use of those agents like the accumulated risk of infection and generalized result throughout the system [6]. the advantages of immunomodulators stem from their ability to stimulate natural and adaptational defense mechanisms, like cytokines, that permits the body to assist itself. The natural immunomodulators act to strengthen weak immune systems and to moderate hyperactive immune systems. Plant sterols and sterolins square measure natural immunomodulators found in some raw fruits and vegetables and, therefore the algae, spirulina. many plants are used traditional knowledge drugs [7]. M. concanensis Nimmo a little tree autochthonal to Northwest Bharat resembling $\mathrm{M}$. oleifera and it's well endowed in Rajasthan, the dry hills of Konkan, state and is usually found on recent deposit land in or close to the sandy beds of rivers and streams [8]. Moringa concanensis Nimmo a medium-sized deciduous tree with thick bark. The bark is fissured to $10 \mathrm{~cm}$ deep and is bad gray. The tree is tonsured except younger elements and inflorescence. Leaves square measure compound (very seldom tripinnate), $45 \mathrm{~cm}$ long. Primary pairs square measure 5-6, distant, $10-20 \mathrm{~cm}$ long. Leaflets square measure 4-6 pairs with AN odd one, loosely elliptic to spherical, blunt at each ends, typically notched at the tip, $2.5-3.8 \mathrm{~cm}$ long, $1.25-2.5 \mathrm{~cm}$ broad, pale at a lower place. Leaf fall is sometimes found in January. Flowering happens throughout February-April. mature is from Gregorian calendar month onward [9]. Herbal medication square measure simply reasonable and fewer potent than artificial prescription immunomodulators and are less seemingly to cause aspect effects. Therefore, there's a necessity to go looking for plants with immunomodulatory activity to supply a completely unique approach for the treatment of communicable disease. The present work was aimed toward the analysis parameters of hand-picked herbs utilized in the treatment of immune malady, a significant incapacitating malady within the world, resulting in vast economic losses.

\section{MATERIALS AND METHODS}

The whole plant of Moringa concanensis was collected from native Mandleshwar, Dist Khargone, Madhya Pradesh, India. The plant was known and genuine by Dr. S K. Mahajan, Ex. Faculty member biological science Department of Govt PG College, Khargone (M. P). A 
voucher specimen (Ref. No. SKM/PGC/Herbarium/2017/A-1)) has been deposited at the division herbarium.

\section{Preparation of extracts}

About 500g of the dried plant powder was placed in the soxhlet apparatus (Perfit, India) and subjected to extraction using ethanol, extracts were filtered and the filtrate was evaporated using a vacuum evaporator (Perfit, India) under reduced pressure at $\leq 50^{\circ} \mathrm{C}$ temperature. The crude extract obtained after evaporation was stored in desiccators. After extraction with a remaining solvent residue of the plant was discarded and the extract was weighed.

\section{Experimental animals}

Albino mice (Swiss) of either sex were used in the present study. The animals were fed with commonplace pellet diet, water spontaneously, and maintained beneath commonplace atmosphere condition utilized. Animals were housed beneath commonplace conditions $\left(22 \pm 5{ }^{\circ} \mathrm{C}\right.$ with twelve $\mathrm{h}$ of light/dark cycle). All experimental protocols have been approved by the Institutional Animal Ethical Committee of BN College of Pharmacy, Bhupal Nobles University, Udaipur (Reg. No 870/PO/Re/S/05/CPCSEA) (Approval Number of IAEC is 15/BNCP/IAEC/2018).

\section{Antigen}

Fresh Sheep blood was collected from a local slaughterhouse in sterile Alsevar's solution (1:1 proportion). Sheep red blood cells (SRBCs) were washed thrice in pyrogens free traditional saline and centrifuged at 2500-3000 rpm for $10 \mathrm{~min}$. The supernatant was removed with pasture pipette and suspended in traditional saline. The concentration of $0.1 \mathrm{ml}$ containing $1 \mathrm{x} 108 / \mathrm{mm} 3$ cells was adjusted by using an improved Neubauer chamber for immunization and challenge.

\section{Chemicals and reagents}

Cyclophosphamide (Khandelwal Laboratories Ltd., Mumbai), lipopolysaccharide and 3-(4,5dimethylthiazol-2-yl)-2,5diphenyltetrazolium bromide (MTT) were purchased from Sigma Chemical Company and all other solvents used for experimental work was of analytical grade.

\section{Acute toxicities}

Acute oral toxicity studies of ethanolic extract of Moringa concanensis and the isolated compound was carried out as per the OECD guidelines, draft guideline 423 adopted on 17 th December 2001, received from Committee for the Purpose of Control and Supervision of Experiments on Animals (CPCSEA), Ministry of Social justice and Empowerment, Govt. of India [10]. Administration of Methanolic extract of Moringa concanensis $50 \mathrm{mg} \backslash \mathrm{kg}$ body weight up to the dose $1700 \mathrm{mg} \backslash \mathrm{kg}$ body weight and administration of isolated compound $50 \mathrm{mg} / \mathrm{kg}$ body weight up to $10 \mathrm{~g} / \mathrm{kg}$ body weight caused no considerable signs of the toxicity in the tested animals.

\section{Experimental design}

\section{Plaque forming cell assay [11]}

On $0 \mathrm{~d}$, all groups were sensitized with $0.1 \mathrm{ml}$ of SRBC containing $1 \times 108$ cells, i. $p$.

Group, I served as control and was administered 1\% Gum acacia suspension in saline

Group II received standard drug $30 \mathrm{mg} / \mathrm{kg}$ bd. wt. cyclophosphamide p. o. respectively ( 1 to 5 d) Group III received $170 \mathrm{mg} / \mathrm{kg}$ bd. wt. of EEMC p. o. respectively (1 to $5 \mathrm{~d}$ ) Group IV received $1 \mathrm{~g} / \mathrm{kg}$ bd. wt. of ICMC p. o. respectively (1 to $5 \mathrm{~d}$ )

The PFC assay was performed using the method of Raisuddin et al. The animals had been humanized on the fifth day of immunization with SRBC. The spleen becomes eliminated, cleaned free of extraneous tissues, and a single cell suspension of 106 cells $/ \mathrm{ml}$ was prepared from it in the RPMI-1640 medium. For PFC assay, the SRBC has been prepared at a density of $5 \times 108$ cells/ml in PBS. One milliliter of SRBC in the medium along with $0.5 \mathrm{ml}$ of diluted rabbit serum complement (1:10 diluted with normal saline) was added to 1 $\mathrm{ml}$ of spleen cell suspension. Cuningham chambers were prepared using glass slides, coverslips, and double-sided tape. The chambers were loaded with a known volume of assay mixture, sealed with petroleum jelly, and incubated at $37^{\circ} \mathrm{C}$ for $1 \mathrm{~h}$. The plaques were counted under a light microscope and expressed as PFC per 106 spleen cells.

\section{Evaluation of nitric oxide (NO) radical scavenging activity [12]}

NO generated from sodium nitroprusside (SNP) was measured using the Griess reagent method whereby $0.5 \mathrm{ml}$ of the test sample was added to $0.2 \mathrm{ml}$ of SNP $(10 \mathrm{mmol})$ and $1.8 \mathrm{ml}$ of phosphate buffer (pH 7.4). The reaction mixture was turned into allowed to incubate at $37^{\circ} \mathrm{C}$ for $3 \mathrm{~h}$. Thereafter, $1.0 \mathrm{ml}$ of the reaction mixture containing nitrite was pipette and mixed with $1.0 \mathrm{ml}$ of Greiss reagent and allowed to stand for $30 \mathrm{~min}$ in diffused light. solution. The absorbance of the pink-colored chromospheres was measured spectrophotometrically at $540 \mathrm{~nm}$ in opposition to the corresponding clean solution.

\section{Cell culture}

The murine macrophage, RAW 264.7 cells, were purchased from American Type Culture Collection and cultured in Dulbecco's modified essential media (DMEM) supplemented with 10\% heatinactivated fetal bovine serum (FBS), streptomycin $(100 \mathrm{mg} / \mathrm{ml})$ and penicillin $(100 \mathrm{U} / \mathrm{ml})$ at $37^{\circ} \mathrm{C}$ in a $5 \%$ CO2 atmosphere. Cells were seeded at a density of $2 \times 106$ onto each well in a 6-well plate for 24 $\mathrm{h}$ before drug treatment.

\section{Measurement of nitric oxide}

The cells were incubated with the test sample at different concentrations $(1.0,0.1$, and $0.01 \mu \mathrm{g} / \mathrm{ml})$. Four hours later, the cells were stimulated with lipopolysaccharides (LPS, $1 \mu \mathrm{g} / \mathrm{ml}$ ) except for the control group for $20 \mathrm{~h}$. The concentration of NO in culture supernatants was determined as nitrite, a major stable product of NO, by the Griess reagent assay. The absorbance of the pink-colored chromospheres was measured spectrophotometrically at $540 \mathrm{~nm}$ against the corresponding blank solution and results were expressed as mmol nitric oxide.

\section{Mtt assay test $[13,14]$}

The 3-(4,5-dimethylthiazol-2-yl)-2,5-diphenyltetrazolium bromide (MTT) assay was used to determine the effect of Pavonia odorata roots plant extract and isolated compound on RAW264.7 cell proliferation. The MTT test measures the capability of cells to convert MTT to formazan. The cells were plated in 96-well tissue culture plates at a density of $5 \times 105$ cells $/ \mathrm{ml}$, in complete DMEM medium and incubated in triplicate in a 96-well plate at a final volume of $100 \mu \mathrm{l}$ for $24 \mathrm{~h}$ at $37^{\circ} \mathrm{C}$ and $5 \%$ CO2 conditions. The cells were treated with Pavonia odorata plant extract and isolated compound at the final concentrations of 25,50 , and $100 \mu \mathrm{g} / \mathrm{ml}$ were incubated for $24 \mathrm{~h}$ at $37{ }^{\circ} \mathrm{C}$ and $5 \% \mathrm{CO} 2$. Then, $10 \mu \mathrm{l}$ of $5 \mathrm{mg} / \mathrm{ml}$ phosphate-buffered saline (PBS) MTT solution was added to each well. After $4 \mathrm{~h}$ of incubation at $37^{\circ} \mathrm{C}$, the media and MTT were aspirated, and $100 \mu \mathrm{l}$ of dimethyl sulfoxide was added to dissolve the yellow MTT tetrazolium salt produced by metabolism to acquire purple MTT formazan salt. The amount of MTT formazan salt produced is proportional to the number of viable cells, and the cell proliferation rate is determined by measuring the absorbance at 570 nm using a microplate reader.

\section{RESULTS AND DISCUSSION}

\section{Plaque forming cell (PFC) method}

EEMC and ICMC were evaluated for in vitro immunomodulatory assay, where ICPO showed good immunomodulatory activity with plaqueforming cells (PFC) (table 1). The number of antibody-secreting cells from spleen was determined using plaque-forming cell assay. The effect of ethanolic extract and isolated compound of Moringa concanensis on antibody-secreting cells of mouse spleen have indicated that immunostimulation was achieved through humoral immunity. The isolated compound effect was significant $\left({ }^{* *} \mathrm{P}<0.01\right)$ compared to control and methanolic extract effect was significant ${ }^{*}(\mathrm{P}<0.05)$. The results obtained in the PFC given in table 1. 
Table 1: Effect of ethanolic extract and isolated compound of Moringa concanensis in vitro immunomodulatory assays

\begin{tabular}{llll}
\hline Groups & Treatment & PFC 106 cells & 0. D 10*106 $^{\mathbf{6}}$ \\
\hline I & CONTROL & $474.8 \pm 0.703$ & $0.623 \pm 0.008$ \\
II & STANDARD & $624.8 \pm 0.703$ & $0.831 \pm 0.007$ \\
III & EEMC & $564.5 \pm 0.587^{*}$ & $0.645 \pm 0.007^{*}$ \\
IV & ICMC & $642.0 \pm 0.573^{* *}$ & $0.720 \pm 0.007^{* *}$ \\
\hline
\end{tabular}

Values are expressed as mean $\mu$ SEM, $(n=6)$. All the groups were compared with control and standard groups using ANOVA followed by Dunnett's ttest. Significant values are expressed as $(\mathrm{p}<0.01)$,

\section{Nitrite scavenging assay}

Table 2 and fig. 2 depicts that at $0.01,0.1$, and $1.0 \mathrm{mg} / \mathrm{ml}$, the Moringa concanensis ethanolic extract and isolated compound of $\mathrm{PO}$ scavenged nitric oxide radicals by 15,23 and $34 \%$, and 22,25,40 respectively, compared to control. Vitamin $\mathrm{C}$ at concentrations of $0.01,0.1$, and $1 \mathrm{mg} / \mathrm{ml}$ exerted 24, 34, and $44 \%$ decrease of nitric oxide radicals, respectively both the sample was the same significant level $\left({ }^{* *} \mathrm{P} \leq 0.001\right)$ compared to control. Although ICMC is more effective than EEMC.

Table 2: Percentage of NO inhibition by Moringa concanensis ethanolic extract and isolated compound

\begin{tabular}{llll}
\hline Concentration in $\boldsymbol{\mu g} / \mathbf{m l}$ & NO Scavenging by Vit C & NO Scavenging by EEMC & NO Scavenging by ICMC \\
\hline 0.01 & $20 \pm 1.73$ & $15 \pm 2.88$ & $24 \pm 1.15$ \\
0.1 & $27 \pm 2.30$ & $23 \pm 0.57$ & $34 \pm 2.30^{* *}$ \\
1 & $52 \pm 3.46$ & $34 \pm 1.73^{* *}$ & $44 \pm 2.88^{* * *}$ \\
\hline
\end{tabular}

Inhibition of NO production by the M concanensis ethanolic extract and isolated compound. Data are mean \pm SEM $(\mathrm{n}=3) ;{ }^{* *} p<0.01$.

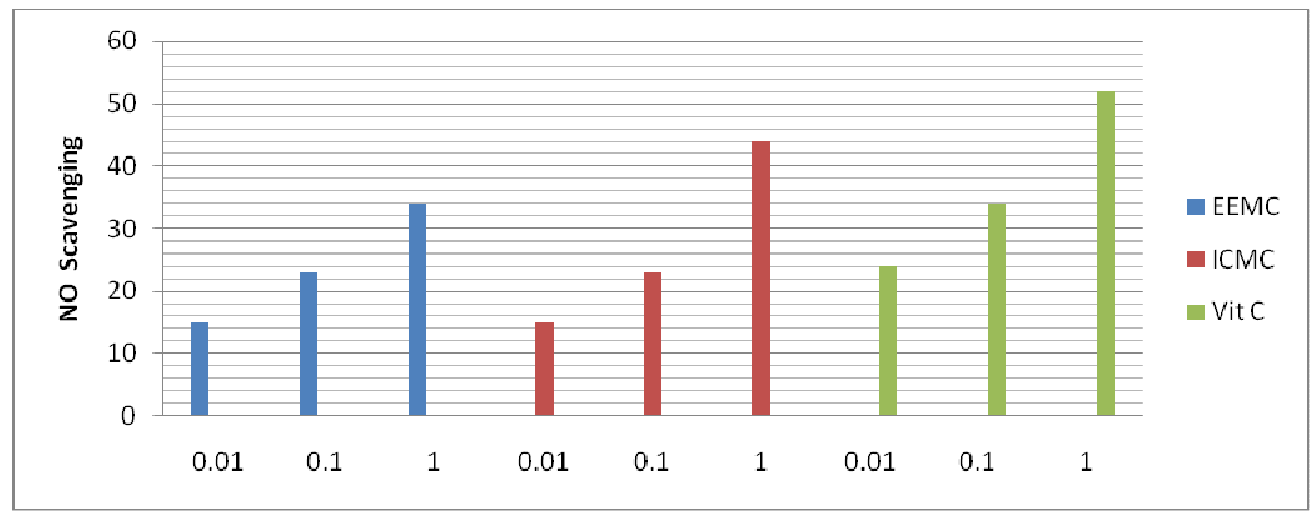

Fig. 1: NO scavenging activity of ethanolic extract Moringa concanensis and isolated compound, data are mean \pm SEM (n = 3); ${ }^{*}<<0.05$ and $* * p<0.01$

\section{LPS induced nitrite oxide assay}

Table 3 and fig. 2 and 3 shows that treatment with LPS induced a high release of NO to the culture medium but pretreatment with Moringa concanensis ethanolic extract and isolated compound resulted in inhibition of NO production by EEMC 29, 37 and $95 \%$ and ICMC 32,44 and $96 \%$ at concentrations of $0.5,0.1$ and 1.0 $\mathrm{mg} / \mathrm{ml}$, compared to LPS-induced sample. ICMC is somewhat more effective than EEMC, but significant $\left({ }^{*} p<0.01\right)$ levels are the same.

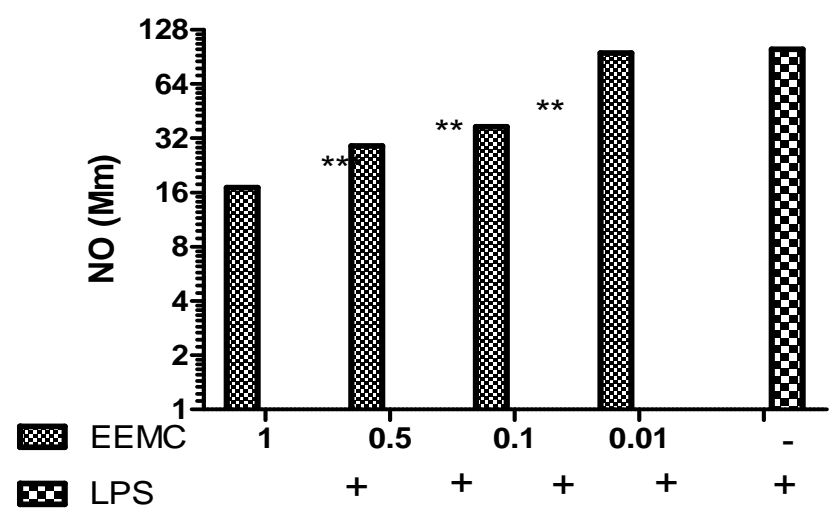

Fig. 2: LPS Induced Inhibition of no production by the Moringa concanensis ethanolic extract, data are mean \pm SEM $(\mathrm{n}=3) * * * p<0.001$ 
Table 3: LPS Induced release of no by Moringa concanensis ethanolic extract and isolated compound

\begin{tabular}{llll}
\hline Concentrations in $\mu \mathrm{g} / \mathbf{m l}$ & LPS & EEMC+LPS & ICMC+LPS \\
\hline 1 & - & $17 \pm 1.73^{* * *}$ & $21 \pm 2.30^{* * *}$ \\
0.5 & - & $29 \pm 1.15^{* *}$ & $32 \pm 2.46^{* *}$ \\
0.1 & - & $37 \pm 4.05^{* *}$ & $44 \pm 1.73^{* *}$ \\
0.01 & - & $95 \pm 1.73$ & $96 \pm 0.57$ \\
1 & 100 & & \\
\hline
\end{tabular}

LPS Induced inhibition of NO by Moringa concanensis ethanolic extract and isolated compound Data are mean \pm SEM $(\mathrm{n}=3) ;{ }^{* *} p<0.01$

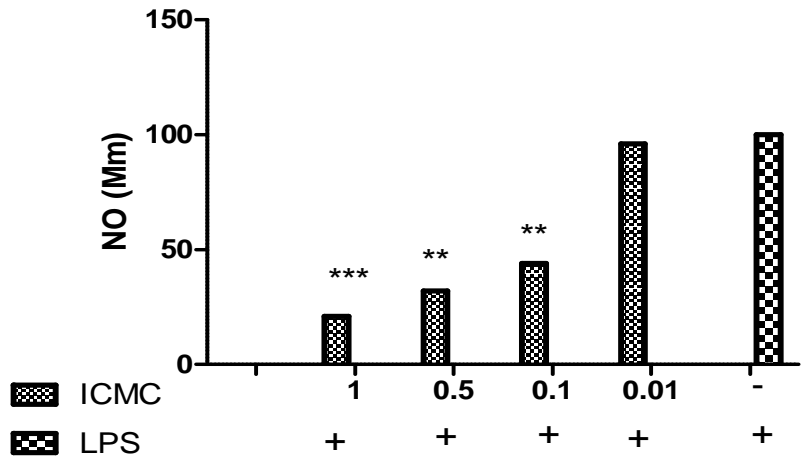

Fig. 3: LPS Induced Inhibition of NO production by the Moringa concanensis isolated compound, data are mean \pm SEM $(n=3){ }^{* * *} p<0.001$

\section{MTT assay}

Table 4 and fig. 4 shows the immunomodulatory effect of the methanolic Pavonia odorata roots extract and isolated compound on the RA264.7 macrophage cell line was investigated by MTT assay.
The results prove that Moringa concanensis stimulates RAW264.7 cell proliferation in a dose-dependent manner. Cell viability significantly increased $(\mathrm{p}<0.001)$ with mean viable cell percent \pm SEM values of EEMC $137 \pm 4.04$ and ICMC $158 \pm 2.88$ at concentration $100 \mu \mathrm{g} / \mathrm{ml}$, ICMC is more cell viability than EEMC.

Table 4: Percent cell viability of ethanolic extract and isolated compound Moringa concanensis and isolated compound their various concentrations by MTT assay

\begin{tabular}{llll}
\hline Concentration in $\mu \mathrm{g} / \mathbf{m l}$ & Control & MTT+EEMC & MTT+ICMC \\
\hline 25 & - & $110 \pm 5.77$ & $116 \pm 1.73^{*}$ \\
50 & - & $117 \pm 1.73^{* *}$ & $143 \pm 0.57^{* * *}$ \\
100 & - & $137 \pm 4.04^{* * *}$ & $158 \pm 2.88^{* * *}$ \\
\hline
\end{tabular}

Percent cell viability of Moringa concanensis and isolated compound their various concentrations Data are mean \pm SEM ${ }^{* *} p<0.01$.

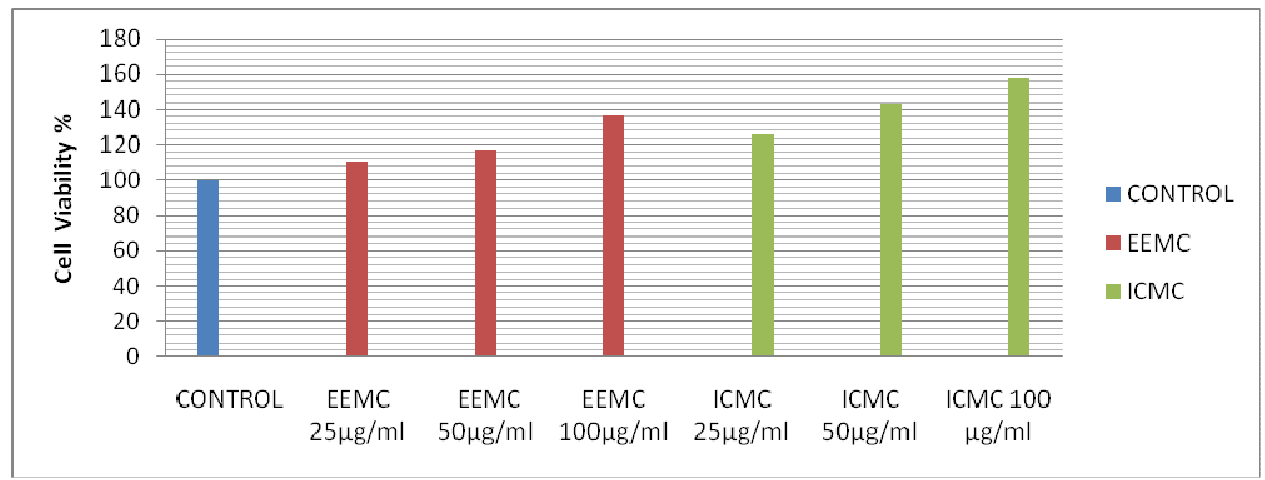

Fig. 4: Each value represents the mean percent \pm SEM significantly different versus control group, $\mathrm{P} \leq 0.05^{*}, \mathrm{P} \leq 0.01^{* *}, \mathrm{P}<0.001^{* * *}$

Ethanolic extracts and the isolated compound was evaluated for in vitro immunomodulatory assay wherever ICMC and EEMC showed smart immunomodulatory activity with plaque-forming cell (PFC) (table 1) the amount of antibody-secreting cells from spleen was firm mistreatment plaque-forming cell assay. The result of the ethanolic extract of Moringa concanensis and Isolated compound on antibody-secreting cells of mouse spleen have indicated that immunostimulation was achieved through humoral mediated immunity. The humoral mediated immunity includes the interaction of B cells with the antigen and their subsequent proliferation and differentiation into antibody-secreting plasma cells. Antibody functions because the effector of the humoral response by binding to antigen and neutralizing it or facilitating its elimination by 
cross-linking to form clusters that are more readily ingested by phagocytic cells [15]. The effect was significant $(\mathrm{P}<0.01)$ compared to control. The humoral mediated immunity involves the interaction of $\mathrm{B}$ cells with the antigen and their subsequent proliferation and differentiation into antibody-secreting plasma cells. Antibody functions as the effector of the humoral immune response by binding to antigen and neutralizing it or facilitating its elimination by cross-linking to form clusters that are more readily ingested by phagocytic cells. The effect of ethanolic extract of Moringa concanensis and the isolated compound has indicated that immunostimulation achieved through humoral immunity.

Table 2 and fig. 1 shows the dose-response result of the NO scavenging activity of the Moringa concanensis and isolated compound These results suggest that ethanolic extract of Moringa concanensis and Isolated compound posses hydrogen donating abilities to act as an antioxidant property [16] fig. 1 depicted that the $0.1,0.01$ and 1.0 $\mathrm{mg} / \mathrm{ml}$ the $\mathrm{M}$ concanensis ethanolic extract scavenged nitric oxide radical by $15,23,34 \%$ and isolated compound scavenged NO by $24,34,44 \%$ respectively compared to control Vit C concentration at $0.1,0.01$ and $1.0 \mathrm{mg} / \mathrm{ml}$ exerted 24,34 and $52 \%$ decrease of nitric oxide radical, respectively. The isolated compound shows the more significance inhibit NO production then methanolic extracts.

Fig. 2 and 3 shows that treatment with LPS induced a high release of NO to the culture medium but pretreatment with Moringa concanensis ethanolic extract and isolated compound resulted in inhibition of NO production by $29,37,95 \%$ and $32,44,96 \%$ at concentrations of $0.5,0.1$ and $1.0 \mathrm{mg} / \mathrm{ml}$, compared to LPS-induced sample. In macrophages, high concentrations of nitric oxide radical can be converted into peroxynitrites, which cause diverse chemical reactions in a biological system, including nitration of tyrosine residue of protein, triggering lipid peroxidation, inactivation of aconites, inhibition of mitochondrial electron transport, and oxidation of biological thiol compounds.[17] The findings of the present study strongly suggest that Pavonia odorata and isolated compound can reduce nitric oxide production by LPS in the RAW 264.7 macrophages

The immunomodulatory effect of the ethanolic Moringa concanensis extract and isolated compound on the RAW264.7 macrophages cell line was investigated by MTT assay. The results prove that $M$ concanensis and isolated compound stimulates RAW264.7 cell proliferation in a dose-dependent manner. Cell viability significantly increased $(* * \mathrm{p}<0.01)$ with mean viable cell percent \pm SEM values of EEMC 110 $\pm 5.77,117 \pm 1.73,137 \pm 4.04$ and ICMC 116 \pm 1.73 , $143 \pm 0.57,158 \pm 2.88$ for 25,50 and $100 \mu \mathrm{g} / \mathrm{ml}$. All the doses after incubation after $24 \mathrm{~h}$ compared with control fig. 4 .

RAW 267.4 macrophage cells were used in this study to determine the immunomodulatory activities The results of this study show that $M$ concanensis and its isolated compound modulate immunity by increasing RAW 264.7 macrophage cell proliferation in a dosedependent These findings indicate the significant immunomodulatory effect of both the plant and its active fraction as immunostimulators. These findings importantly show that the isolated compound of Moringa concanensis very suitable candidate for modulating macrophage function and inducing the immune system.

\section{CONCLUSION}

This study concluded that the ethanolic extract of Moringa concanensis and isolated compound both possesses significant immunomodulatory potential depends on increases antibodysecreting cell of plaque-forming cell and inhibition of NO production of nitric oxide scavenging which confers the immunostimulating activity. Hence, these plant additional scientific attention to actualize its potentialities within the field of drugs and health sciences.

\section{ACKNOWLEDGMENT}

The author is thankful to BN College of Pharmacy, Bhupal Nobles University, providing good facilities and infrastructure to carry out the project.

\section{FUNDING}

This research did not receive any specific grant from funding agencies in the public, commercial, or-not-for-profit sectors.

\section{AUTHORS CONTRIBUTIONS}

All the authors have contributed equally.

\section{CONFLICT OF INTERESTS}

The authors hereby declare that they have no conflicts of interest either to disclose

\section{REFERENCES}

1. Uniyal SK, KN Singh, $\mathrm{P}$ Jamwal, B Lal. Traditional use of medicinal plants among the tribal communities of chotta bhangal, western Himalayan. J Ethnobiol Ethnomed 2006;2:1-4.

2. Alamgir M, Uddin SJ. Recent advances on the ethnomedicinal plants as immunomodulatory agents. Ethnomedicine: a source of complementary therapeutics. Debprasad Chattopadhyay 2010;695:227-44.

3. Kuttan G. Immunomodulatory effect of come naturally occurring sulfur-containing compounds. J Ethnopharmacol 2000;72:93-9.

4. Bodhankar S, Makare N, Rangari V. Immunomodulatory activity of alcoholic extract of Mangifera indica L. in mice. J Ethnopharmacol 2001;78:133-7.

5. Pezzuto JM. Plant-derived anticancer agents. Biochem Pharmacol 1997;53:121-33.

6. Diasio RB, LoBuglio AF. The pharmacological basis of therapeutics. In: Goodman, Gilman's. editors. McGraw-Hill (NY); 1996. p. 1291-307.

7. Patil US, Jaydeokar V, Bandawane DD. Immunomodulators: a pharmacological review. Int J Pharm Pharm Sci 2012;4:30-6.

8. Anbazhakan S, Dhandapani R, Anandhakumar P, Balu S. Traditional medicinal knowledge on Moringa concanensis nimmo of perambalur district, Tamilnadu. Anc Sci Life 2007;26:42-5.

9. Ankita Dey, Bhattacharyya Sauryya, Pal Tapan Kumar. Antioxidant activities of moringa concanensis flowers (fresh and dried) grown in West Bengal. Int J Res Chem Environ 2014;4:64-70.

10. OECD: Guideline, 423, acute oral toxicity: Environmental Health and Safety Monograph series on Testing and Assessment; 2000.

11. Satish Verma K, Asima Shaban, Reena Purohit, Madhvi Chimata L, Geeta Rai, Om Prakash Verma. Immunomodulatory activity of Withania somnifera (L.). J Chem Pharm Res 2012;4:559-61.

12. Sneha J Anarthe, E Malavika, A Pravalika, M Ganga Raju. Screening of immunomodulatory activity of spahaeranthus idicus linn whole plant. Int J Phytomed 2015. p. 432-40.

13. Jin Won Chung, Jin Uk Oh, Sehyung Lee, Sung-Jin Kim. Inhibition of inducible nitric oxide synthase, cyclooxygenase-2, and lipid peroxidation by methanol extract of Pericarpium Zanthoxyli. Trop J Pharm Res 2013;12:369-75.

14. Guan D, Zhang Z, Yang Y, Xing G, Liu J. Immunomodulatory activity of polysaccharide from the roots of Actinidia kolomikta on macrophages. Int J Biol 2011;3:3-10.

15. Groesdonk HV, Schlottmann S, Richter F, Georgieff M, Senftleben U. Escherichia coli prevents phagocytosis-induced death of macrophages via classical NF- $\mathrm{B}$ signaling, a link to Tcell activation. Infect Immun 2006;74:5989-6000.

16. Liyana Pathirana CM, Shahidi F. Antioxidant properties of commercial soft and hard winter wheats (Triticumaestivum L.) and their milling fractions. J Sci Food Agric 2006;86:477-85.

17. Yermilov V, Rubio J, Becchi M, Friesen MD, Pignatelli B, Ohshima H. Formation of 8-nitroguanidine by the reaction of guanine with peroxynitrite in vitro. Carcinogenesis 1995;16:2045-50. 